\title{
Outcomes of Acinetobacter baumannii infection in critically ill elderly patients in intensive care units
}

\author{
Yoğun bakım ünitesinde yatan yaş/ı hastalarda Acinetobacter baumannii enfeksiyonunun \\ sonuçları
}

\author{
Kevser Özdemir*, Hüseyin Turgut ${ }^{\star *}$, Asiye Dikmen ${ }^{* * *}$, Ahmet Bacanlı*, Ferzan Göncü ${ }^{*}$ \\ *Denizli Devlet Hastanesi, Enfeksiyon Hastalıkları ve Klinik Mikrobiyoloji Kliniği, Denizli \\ **Gazi Üniversitesi Diş Hekimliği Fakültesi, Anesteziyoloji ve Reanimasyon AD, Ankara \\ ${ }^{* * * G a z i ~ U ̈ n i v e r s i t e s i ~ T ı p ~ F a k u ̈ l t e s i, ~ H a l k ~ S a g ̆ l ı g ̆ ı ~ A D, ~ A n k a r a ~}$
}

\begin{abstract}
Purpose: In this study we aimed to investigate the incidence and effect of Acinetobacter baumannii infection on mortality in elderly patients admitted to intensive care unit.

Materials and methods:We retrospectively investigated the medical records of elderly patients $>65$ years) treated for more than 48 hours in our intensive care unit between 2013-2014. Defined risk factors in patients with or without $A$. baumannii infection were compared.

Results: Medical records of one hundred and four patients mean age of patients was $77.1 \pm 6.9$ were investigated. Most common nosocomial infection was ventilatory associated pneumonia in patients with $A$. baumannii infection $(62.5 \%)$. Urinary catheter insertion was the most common invasive intervention (99\%). Invasive interventions for instance; central venous catheterization, urinary catheter, mechanical ventilation and nasogastric tube insertion are defined as risk factors for $A$. baumannii infection, only mechanical ventilation is defined as independent risk factor $(p=0.001)$. Mortality rates were significantly higher in patients infected with $A$. baumannii than non-infected patients $(p=0.026)$.

Conclusion: We showed that nosocomial $A$. baumannii infection leads higher mortality rates $(p<0.05)$. Elderly patients prone to infections so this group of patients need to be evaluated as special patient population. All precautions have to be taken in order to avoid nosocomial infections and decrease mortality rates.
\end{abstract}

Pam Med J 2015;8(2):100-104

Key words: Acinetobacter baumannii, elderly, intensive care units, mortality, nosocomial infection.

\section{Özet}

Amaç: Çalışmamızda yoğun bakım ünitesinde yatan yaşlı hastalarda ortaya çıkan Acinetobacterbaumannii enfeksiyonunun sıklı̆ını ve mortalite üzerine olan etkisini göstermeyi amaçladık.

Gereç ve yöntem: Çalışma retrospektif olarak 2013-2014 tarihleri arasında medikal yoğun bakım ünitelerinde 48 saatten uzun süre yatan $\geq 65$ yaş üstü hastalar ile yapılmıştı. A. baumannii enfeksiyonu olan ve olmayan hastalar risk faktörleri açısından karşılaştırılmıştır.

Bulgular: Çalışmada yaş ortalaması $77.1 \pm 6.9$ olan 104 hasta değerlendirildi. A. baumannii enfeksiyonu olan hastalarda en sık hastane enfeksiyonu ventilatör ilişkili pnömoni (\%62.5) olarak bulunmuştur. En sık uygulanan invaziv girişim üriner katater olarak tespit edilmiştir (\%99). Uygulanan invaziv girişimlerin hepsi A. baumannii için risk faktörü olmakla birlikte mekanik ventilasyon bağımsız risk faktörü olarak saptanmıştır $(p=0.001)$. Mortalite ise $A$. baumannii enfeksiyonu olanlarda olmayanlara göre anlamlı olarak yüksek bulunmuştur $(p=0.026)$.

Sonuç: Yaşlı hastalarda hastane kaynaklı A. baumannii enfeksiyonu mortaliteyi artırmaktadır $(p<0.05)$. Yaşı hastalar enfeksiyona yatkınlık bakımından özel hasta grubu olarak ele alınmalı, hastane enfeksiyonundan korumak ve mortaliteyi azaltmak için gerekli enfeksiyon kontrol önlemleri alınmalıdır.

Pam Tıp Derg 2015;8(2):100-104

Anahtar sözcükler: Acinetobacter baumannii, yaşlı, yoğun bakım ünitesi, mortalite, hastane enfeksiyonu.

Kevser Özdemir

Yazışma Adresi:Denizli Devlet Hastanesi, Enfeksiyon Hastalıkları ve Klinik Mikrobiyoloji Kliniği, Denizli e-mail: drkevser@gmail.com

Gönderilme tarihi: 14.10.2014 Kabul tarihi: 24.12.2014 


\section{Introduction}

A rising percentage of elderly is going to increase in many countries of the world. Increase in elderly population results in increased elderly patients in intensive care unit (ICU) [1]. Defects in immunity, chronic co-morbidities, decreased tolerance to treatments secondary to anatomic and functional alterations facilitate development of infectious disease in this patient group. As a result elderly patients stay in ICU longer and suffer from nosocomial infection (NI) more commonly [2]. In our country the ratio of elderly in the population was $4.6 \%$ in 1980 while $7.5 \%$ in 2012. Worldwide data is similar to data from Turkey. Estimated ratio of elderly to overall population is twenty percent $[3,4]$.

Acinetobacter species are opportunistic, obligate aerobic, nonfermentative gram negative patogen bacillaries. Thirty two different genomic species were defined and Acinetobacter baumannii is the most common nosocomial infection agent [5]. This pathogen can be isolyted from many different materials and survive in non-suitable hospital environment for a long time [6]. A. baumannii species have intrinsic resistance to many antibiotics and also development of rapid resistance has been reported [7]. Increased resistance development and infection incidence are main difficulties in managing Acinetobacter infections [8].

Nosocomial infections in elderly increases mortality rates $[4,9,10]$. Recently increased nosocomial infections with $A$. baumannii in ICU have been reported however there is no study investigates effects of $A$. baumannii infections in elderly [11]. In this study we investigated A. baumannii infection rates and effects on mortality in elderly patients stayed more than 48 hours in our ICU.

\section{Materials and Methods}

This study was conducted in intensive care units in Denizli State Hospital. There are 38 ICU beds in these third stage ICU's. We retrospectively investigated the records of patients admitted in ICU between January 2013 and January 2014 with active prospective surveillance. We enrolled patients $>65$ years (defined as elderly according to World Health Organization (WHO) and stayed more than 48 hours in ICU [12]. Patients infected with A. baumannii at admission were excluded. Demographical data, underlying diseases, duration of ICU stay, applied invasive interventions, diagnoses at admission, nosocomial infections and mortality rates were noted. Nosocomial infections were diagnosed using criterias established by Centers for diseases control and prevention (CDC) [13].

Statistical analysis was performed using SPSS software (SPSS version 16, Chicago, IL). Definitive statistics (frequency, percentage distrubition) were used in order to analyse data. Qualitative data were analysed with chi-square test while quantitative data of independent groups were analysed with t test. Correlation and regression tests were used to measure riskfactors. In correlation analysis for mortality $p<0.20$ up to the variables (central venous catheterization, ventilatory associated pneumonia, urinary infection taract nasogastric tube, Acinetobacter) was taken to the regression model.

\section{Results}

One hundred and seventy two patients that treated more than 48 hours in ICU were enrolled in the study. Sixty eight of these were under 65 years old so this group was excluded from study. Mean age of patients was $77.1 \pm 6.9$ years and $56(53.8 \%)$ of them were female. Charecteristics and clinical features of patients were shown in Table 1. Cerebrovascular disease was the most common underlying disease. Most frequent symptom at admission was respiratory failure. Urinary catheter was inserted in ninenty nine percent of patients. Most frequent isolated nosocomial infection agent was $A$. baumannii $56(53.8 \%)$ while Pseudomonas aeruginosa $16(15.3 \%)$ was the second most common isolated agent. Urinary tract infection has been taken the first place between NI's while ventilatory associated pneumonia (VAP) was the second most common form of NI 45 (43.3\%) (Table 1). A. baumannii infection was developed in 56 patients $(53.8 \%)$. There was no significant difference between gender. Characteristics of patients with/without $A$. baumannii infection were shown in Table 2. Higher percentage of mechanical ventilation (MV) and central venous catheter usage were found in association with A. baumannii infections $(p<0.05)$. Ventilatory associated pneumonia $35(62.5 \%)$ was the most common $\mathrm{NI}$ in patients with A.baumanni infection while in non-infected group urinary tract infection (UTI) $31(64.6 \%)$ was the most NI. Mortality rate was $44(78.6 \%)$ in patients infected with $A$. baumannii. We found significant difference between two groups in terms of mortality rates $(p<0.05)$ (Table 2$)$.

A. baumannii was found as an independent risk factor for mortality $(p=0.026)$. Regression 
analyse revealed that $A$. baumanni infection is related with higher mortality risk than non infected patients. Another risk factor associated with increased mortality risk was nasogastric tube insertion $(p=0.003)$. Multivariate analyse showed that MV is an independent risk factor for $A$. baumannii infection $(p=0.001)$. Other variables age, gender, ICU stay, central venous catheter insertion, total parenteal nutrition (TPN), chronic diseases- were not identified as independent risk factors for Acinetobacter infection and mortality.

Table 1. Demographic and clinical characteristics of patients

\begin{tabular}{ll}
\hline Variables & All patients $\mathbf{n}=\mathbf{1 0 4}(\mathbf{\%})$ \\
\hline Age & $77.1(65-92)$ \\
Male & $48(46.2)$ \\
Underlying chronic disease & $89(85.6)$ \\
Admission diagnosis & \\
Sepsis & $16(15.4)$ \\
Neurologic disorder & $27(26.0)$ \\
Respiratory failure & $33(31.7)$ \\
ARDS & $17(16.3)$ \\
Gastroenterological disorder & $11(10.6)$ \\
Mechanical ventilation & $81(77.9)$ \\
Urinary catheter & $103(99)$ \\
Central venous catheter & $68(65.4)$ \\
Length of ICU stay day & $40.3(4-180)$ \\
Mortality & $72(69.2)$ \\
\hline
\end{tabular}

ARDS:Acute Respiratory Distress Syndrome

Table 2. Comparison of patients with and without $A$. baumannii infection

\begin{tabular}{lccc}
\hline Variables & $\begin{array}{c}\text { Patients with } \\
\text { A.baumannii } \mathbf{n = 5 6} \text { (\%) }\end{array}$ & $\begin{array}{c}\text { Patients without } \\
\text { A.baumannii } \mathbf{~}=\mathbf{4 8} \text { (\%) }\end{array}$ & $\mathbf{p ~}$ \\
\hline Sex & $30(53.8)$ & $26(46.4)$ & - \\
$\quad$ Female & $26(46.2)$ & $22(45.8)$ & - \\
$\quad$ Male & $46(82.1)$ & $43(89.6)$ & 0.40 \\
Chronic Disease & $53(94.6)$ & $28(58.3)$ & 0.00 \\
Mechanical ventilation & $55(98.2)$ & $48(100)$ & 1 \\
Urinary catheter & $43(76.8)$ & $25(52.1)$ & 0.01 \\
Central venous catheter & $27(48.2)$ & $22(45.8)$ & 0.84 \\
Presence of nasogastric tube & $30(53.6)$ & $19(39.6)$ & 0.23 \\
TPN & $35(62.5)$ & $10(20.8)$ & 0.00 \\
Ventilator-associated & $19(33.9)$ & $31(64.6)$ & 0.03 \\
pneumonia & $15(26.8)$ & $10(20.8)$ & 0.5 \\
Urinary tract infection & $44(78.6)$ & $28(58.3)$ & 0.03 \\
Bloodstream infection & 40.9 & 39.75 & 0.85 \\
Mortality & & & \\
Length of ICU stay day & & & \\
\hline Values are presented $\mathrm{n}$ (\%) & & & \\
TPN: Total Parenteral Nutrition & & & \\
\hline
\end{tabular}

\section{Discussion}

Identifying risk factors for development of $A$. baumannii infections in elderly as likely in other age groups is essential in order to infection control and decreasing $\mathrm{NI}$ related mortality as true for other age groups of patients.

Percentage of elderly patients in our ICU was $60 \%$ while this ratio changes between
$45-50 \%$ in similar studies [14]. Nosocomial infections in elderly ICU patients is a common problem. According to NNIS reports the NI ratio as $54 \%$ in elderly population [15]. There are several studies showed advanced age as a risk factor for developing NI $[16,17]$. Contrary several studies showed no positive correlation between advanced age and NI however they showed higher mortality rates in patient with NI [4,9]. Kaye et al. [9] showed that blood 
stream infections in elderly lead increased mortality hospital stay and costs. Similarly another study showed no correlation between advanved age and increased VAP incidence however authors reported higher mortality rates in elderly patients suffered from VAP [10]. A. baumannii infection has become a life threatened factor for ICU patents in Asian, European countries and also in our country during recent years [11]. Studies showed that A. baumannii infection was an important factor that lead increased mortaliy and morbidity rates in ICU $[18,19]$. However several other studies showed $A$. baumannii infections alone were not related with increased mortality rates [20]. Daniels et al. [21] showed no correlation between higher mortality rates and $A$. baumannii infection in surgical ICU patients. Turkoglu et al. [22] showed higher mortality rates in patients with hematological malignancies infected with $A$. baumannii although infection was not an independent risk factor alone. Our results showed higher mortality rates in elderly patients infected with $A$. baumannii. This result is correlation with studies accepted $A$. baumannii as an independent risk factor for mortality [22].

Most common forms of $\mathrm{NI}$ in ICU of country hospitals are VAP, UTI and bloodstream infection (BSI). However in our ICU most common form is UTI while VAP and BSI are following UTI. This can be explained with high UC usage in our hospital. Common result of all studies is when more invasive intervention applied NI incidence increses [4,23]. Ventilatory associated pneumonia incidence increases 10$20 \%$ with ICU stay longer than 48 hours and infection is associated with increased mortality and hospital stay $[8,10]$. Most common $A$. baumannii associated VAP infectious state is and BSI [5,24]. Other clinical states are UTI, skın and soft tıssue infections, wound infections and secondary meningitis [25].

In our study most common $A$. baumannii associated NI was VAP. Respiratory failure and tracheal intubation facilitate $A$. baumannii colonisation that followed by bacteriemia [8]. Blot et al. concluded that VAP incidence in elderly is similar with other age groups however hospital stay costs and mortality rates are significantly increases in this patients [10]. Defined risk factors for $A$. baumannii infection are invasive interventions long ICU stay, advanced age nasogastric tube insertion, broad spectrum antibiotic regimens and TPN [22,24-26]. In our study only MV was found as an independent risk factor for $A$. baumannii infection development.
The differences in study designs ICU patterns and patient status can result in different study results. Decreasing the frequency of applied invasive interventions is an important precaution in terms of avoiding infections. There are several limitations of our study. First this is a single centered study. The second one APACHE II scores have not being used to investigate mortality rates. An important finding of this study is to determine the $A$. baumannii infection as an independent risk factor for higher mortality rates.

In conclusion we can conclude that $A$. baumannii infection leads increased mortality rates in elderly patients. Several factors include increased antibiotic resistance difficult environment eradication arise difficulties during treatment process. Several factors have to be kept in mind in order to decrease $A$. baumannii associated infections and mortality rates. Strictly attending infection control precautions, to be aware of weakened immune system of elderly, decreasing the use of broad spectrum antibiotic regimens, using agent specific antibiotics and avoiding unnecessary invasive interventions may result in decreased $A$. baumannii associated $\mathrm{NI}$ and mortality.

Conflict of interest: The authors declared no conflict of interest.

\section{References}

1. Ulger Z, Cankurtaran M. Elderly patients in intensive care units. Turkish J Int Care Med 2006;6:94-100.

2. Liang SY, Mackowiak PA. Infections in the elderly. Clin Geriatr Med 2007;23:441-456.

3. Kinsella K, Wan H, Census Bureau US. International population reports. An Aging World: 2008, WashingtonU.S. Government Printing Office, DC, 2009:1-209.

4. Ozdemir K, Dizbay M, Dikmen A. Incidence and risk factors of nosocomial infections in elderly and adult patients in intensive care units. Turkish $\mathrm{J}$ Geriatr 2013;16:155-160.

5. Murray CK, Hospenthal DR. Acinetobacter infection in the ICU. Crit Care Clin 2008;24:237-248.

6. Mera RM, Miller LA, Amrine-Madsen H, Sahm DF. Acinetobacter baumannii 2002-2008: Increase of carbapenem-associated multiclass resistance in the United States. Microb Drug Resist 2010;16:209-215.

7. Friedland I, Stinson L, Ikaiddi M, Harm S, Woods GL. Phenotypic antimicrobial resistance patterns in Pseudomonas aeruginosa and Acinetobacter: results of a Multicenter Intencive Care Unit Surveillance Study, 1995-2000. Diagn Microbiol Infect Dis 2003;45: 245-250.

8. Kim SY, Jung JY, Kang YA, et al. Risk factors for occurance and 30-day mortality for carbapenem- 
resistant Acinetobacter baumannii bacteremia in a intensive care unit. J Korean Med Sci 2012;27:939947.

9. Kaye KS, Marchaim D, Chen TY, et al. Effect of nosocomial bloodstream infections on mortality, length of stay, and hospital costs in older adults. J Am Geriatr Soc 2014;62:306-11.

10. Blot S, Koulenti D, Dimopoulos G, et al. Prevalence, risk factors, and mortality for ventilator-associated pneumonia in middle-aged, old, and very old critically ill patients. Crit Care Med 2014;42:601-609.

11. Falagas ME, Karveli EA, Siempos II, Vardakaz KZ. Acinetobacter infections: a growing threat for critically ill patients. Epidemiol Infect 2008;136:1009-1019.

12. World Health Organization, World Health Report, Geneva 1998;7:251.

13. Horan T, Andrus M, Dudeck M. CDC/NHSN surveillance definition of healthcare-associated infection and criteria for specific types of infections in the acute care setting. Am J Infect Control 2008;36:309-332.

14. Topeli A. Elderly patient in the intensive care unit. Turkish J Geriatr 2000;3:151-154.

15. Emori TG, Banarjee SN, Culver DH, et al. Nosocomial infections in elderly patients in the United States, 19861990. National Nosocomial Infections Surveillance System. Am J Med 1991;91(3B):285-2935.

16. Dimopoulos G, Koulenti D, Blot S, et al. Critically ill elderly adults with infection: analysis of the extended prevalence of infection in intensive care study. J Am Geriatr Soc 2013;61:2065-2071.

17. Ribas RM, Gontijo Filho PP. Comparing hospital infections in the elderly versus younger adults: an experience in a Brazilian University Hospital. Braz J Infect Dis 2003;7:210-215.

18. Falagas ME, Bliziotis IA, Siempos II. Attributable mortality of Acinetobacter baumannii infections in critically ill patients: a systematic review of matched cohort and case-control studies. Crit Care 2006;10:R48.
19. Fagon JY, Chastre J, Domart Y, Trouillet JL, Gibert C. Mortality due to ventilator-associated pneumonia or colonization with Pseudomonas or Acinetobacter species: assessment by quantitative culture of samples obtained by a protected specimen brush. Clin Infect Dis 1996;23:538-542.

20. Jang $\mathrm{TN}$, Lee $\mathrm{SH}$, Huang $\mathrm{CH}$, Lee $\mathrm{CL}$, Chen WY. Risk factors and impact of nosocomial Acinetobacter baumannii bloodstream infections in the adult intensivecare unit: a case-control study. J Hosp Infect 2009;73:143-150.

21. Daniels TL, Deppen S, Arbogast PG, Griffin MR, Schaffner W, Talbot TR. Mortality rates associated with multidrug-resistant Acinetobacter baumannii infection in surgical intensive care units. Infect Control Hosp Epidemiol 2008;29:1080-1083.

22. Turkoglu M, Mirza E, Tunçcan OG, et al. Acinetobacter baumannii infection in patients with hematologic malignancies in intensive care unit: risk factors and impact on mortality. J Crit Care 2011;26:460-467.

23. Vincent JL, Bihari DJ, Suter PM, et al. The prevalence of nosocomial infection in intensive care units in Europe. Results of the European Prevalence of Infection in Intensive Care (EPIC) Study. EPIC International Advisory Committee. JAMA 1995;274:639-644.

24. Kalin G, Alp E, Akin A, Coskun R, Doganay M. Comparision of colistin and colistin/sulbactam forthe treatment of multidrug resistant Acinetobacter baumannii ventilator-associated pneumonia. Infection 2014;42:37-42.

25. Dijkshoorn L, Nemec A, Seifert H. An increasing threat in hospitals: multidrug-resistant Acinetobacter baumannii. Nat Rev Microbiol 2007;5:939-951.

26. Tekin R, Dal T, Bozkurt F, et al. Risk factors for nosocomial burn wound infection caused by multidrug resistant Acinetobacter baumannii. J Burn Care Res 2014;35:e73-80. 